\title{
Electrical model of Cambrian rocks from Volodymyrska area in Volyno-Podillia (Ukraine)
}

\begin{abstract}
This paper focuses on the techniques and results of electrical research into complex terrigenous and carbonate reservoirs. Presented here, are the electric data and their relation to the capacity properties of Cambrian sandstones, limestones and dolomites originating from the Volodymyrska area in Volyno-Podillia (Ukraine). Their petroelectrical models are generated.
\end{abstract}

Key words: reservoirs, porosity, permeability index, resistivity, formation resistivity factor, water saturation factor, resistivity increasing coefficient, sandstone, limestone and dolomite.

\section{Elektryczny model skał kambryjskich z obszaru Volodymyrska na Vołyno-Podolu (Ukraina)}

Artykuł skupia się na technikach i wynikach badań elektrycznych w złożonych zbiornikach terygenicznych i węglanowych. Prezentowane są tu dane elektryczne i ich związek z właściwościami pojemności kambryjskich piaskowców, wapieni i dolomitów pochodzących z obszaru Volodymyrska na Vołyno-Podolu (Ukraina). Ich petroelektryczne modele są generowane.

Słowa kluczowe: skała zbiornikowa, badania elektryczne.

\section{Introduction}

The intricate correlation between capacity and filtration features, logging and field geophysical data requires a thorough analysis based on petrophysical laboratory study. A crucial factor in determining the geoelectrical properties of rocks is electrical resistivity $(\rho)$, which is determined by rock composition and texture, capacity space structure, oilgas- and water saturation of rocks, porosity factor, reservoir water salinity, temperature and pressure [1-8].

The main purpose was to develop an electrical model of reservoir rocks so as to provide the basis for a comprehensive analysis of their electrical parameters and their relation to capacity and filtration properties. Determining reservoir rock resistivity is essential for clarification of the variation range for certain types and groups of rocks, determining individual stratigraphic horizons, sections and facies; revealing the correlation between resistivity and a number of attributes, such as mineral composition, pore space structure, the phase relation of matter, frequency and tension of the electric field, as well as identifying the nature of changes in electrical resistivity under epigenetic transformations and metamorphic changes in rocks.
Laboratory data on resistivity variation in rocks are used in electrical logging interpretation and field electrical exploration.

This paper presents the results of petroelectrical laboratory analysis of Cambrian sandstones, limestones and dolomites from the Volodymyrska area, which is prospective for hydrocarbons (Volodymyrska-1 and Volodymyrska-2 wells, the interval $1190 \div 2520 \mathrm{~m}$ ). The area is located in the northern part of the eastern side of the Lviv Paleozoic rock bend, in the Volyno-Podillia edge of the East-European platform.

The following summarizes petrographic characterization of typical species of the Cambrian rocks of the Volodymyrska area that is prospective for hydrocarbons.

1. Dolomites gray with a greenish tinge (intervals $1188 \div 1196 \mathrm{~m}, 1800 \div 1808 \mathrm{~m}$ and $1995 \div 2005 \mathrm{~m}$ ) (Fig. 1a). The color is gray with a greenish tint. The texture is well equipped, poorly-layered. The rock is dense, slightly porous. The shear surface is flat and rough to the touch. The structure is finely crystalline. The composition of rocks: micrite dolomite, calcite, smectites. 
2. Dolomitized limestone, organic-detritic, crinoidal (intervals $1820 \div 1824 \mathrm{~m}, 1831 \div 1842 \mathrm{~m}$ and $1885 \div 1895 \mathrm{~m}$ ) (Fig. 1b). The laminated color changed from dark gray to brownish gray. The texture is foliated. Texture features are observed in polished sections. The shear surface is bumpy, with sharp edges, rough to the touch due to impurities of silt material. The rock is strong, slightly porous. The structure is cryptocrystalline (micrite), uniform in the areas of clusters of shells - organic-detritic.

Ingredients: micrite dolomite, calcite, residues of calcite, there are few scales of chlorite and hydromica.
3. Silt sandstone, gray (interval $2189 \div 2200 \mathrm{~m}, 2210 \div 2219 \mathrm{~m}$, $2263 \div 2276 \mathrm{~m}, 2296 \div 2304 \mathrm{~m}, 2520 \div 2526 \mathrm{~m}$ ) (Fig. 1c).

The color is gray; to a depth of $3 \mathrm{~mm}$ the color of the sample is ocher-brown.

The texture is not foliated. The shear surface is rough, slightly bumpy, stepped. The rock is cemented, but dusty to the touch. The rock is porous, has the smell of hydrocarbons. The structure is fine-grained. The composition of rocks: debrises psammitic and silt dimension $-70 \%$, cement is incomplete, micaceous-clayed, porous-opened.
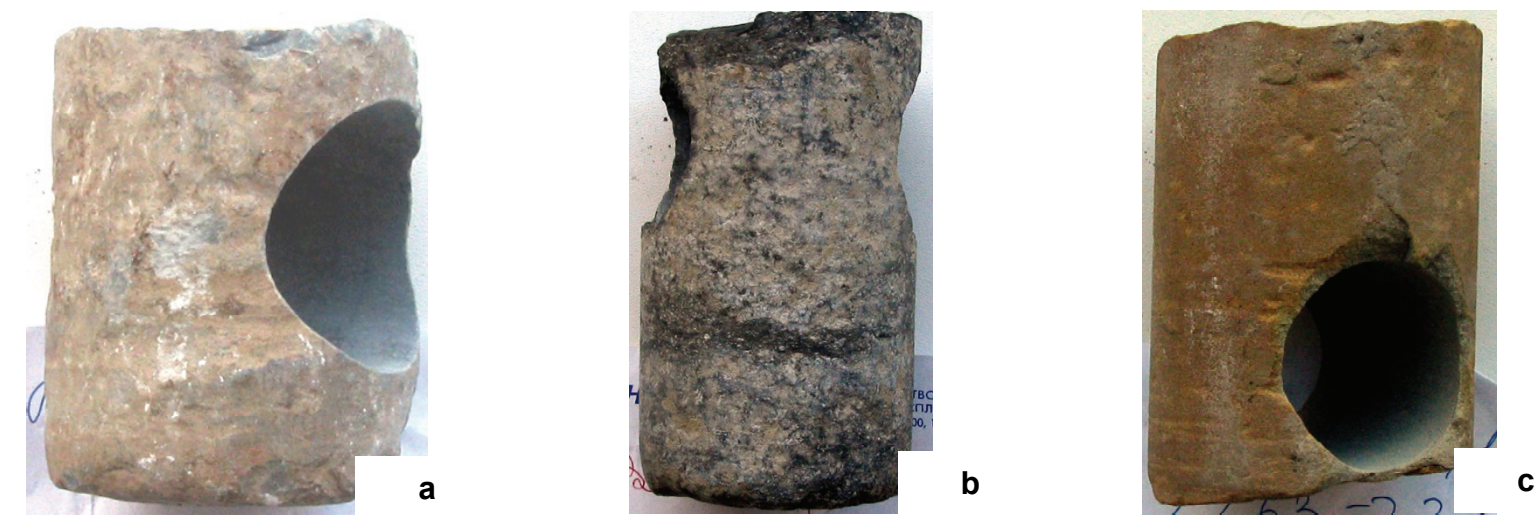

Fig. 1. The samples of rocks: $\mathrm{a}$ - dolomite, $\mathrm{b}$ - limestone, $\mathrm{c}-$ sandstone

\section{Experiment}

A series of laboratory experiments involved identifying the density of the rocks under study (dry and saturated with synthetic brine), open porosity (method of nitrogen saturation and method of synthetic brine saturation), residual water saturation factor (by centrifugation), permeability (nitrogen filtration method), interval time (velocity of P-waves) and resistivity. In the laboratory experiments, we determined electrical resistivity of rock samples under various conditions (dry, partially and completely saturated with reservoir synthetic brine) under atmospheric conditions and under those close to the reservoir.

Laboratory electrometric measurements of dry core samples were performed at a temperature of $20^{\circ} \mathrm{C}$ with a digital megaohmmeter C.A 6547, which ensures high-precision measurement of electrical resistivity in the range $10 \mathrm{kOhm}$ to 10 TOhm, using a DC two-electrode scheme, with computerized digital recording $[2,3,5,4,6]$. For $\mathrm{NaCl}(\mathrm{M}=30 \mathrm{~g} / \mathrm{l})$ saturated samples, RCL-meter MHC-1100 was used. Cylindrical samples to be tested were placed in a special core holder with nonpolarized electrodes, which are specially made from graphitized rubber. In order to determine the correlation between the petrophysical parameters and the water saturation levels (and hence oil and gas saturation) of rocks, we studied the changes in resistivity while stripping water on centrifuge OS-6M.

Electrical analysis involved repeated measuring of electrical resistivity in core samples saturated with synthetic brine. Measurements were performed before and after centrifugation in stripping modes from 1000 to $6000 \mathrm{rev} / \mathrm{min}$. with a measurement pitch of $1000 \mathrm{rev} / \mathrm{min}$., water displacement pressure ranging from 0.2 to $1.0 \mathrm{MPa}$ (7 measurement cycles). Simultaneously, water saturation factor and the velocity of elastic waves were being determined. The mean relative error of electrical resistance was estimated to be $2.4 \%$ (permissible error is $5 \%$ ).

Data analysis. Petrophysical laboratory research yielded data on porosity, permeability and electric properties of the major types of rocks, as shown in Table 1.

The laboratory measurements showed that resistivity values, measured on dry extracted samples (electrical resistivity of mineral skeleton) ranges from 0.52 (sandstone) to 24.442 $\mathrm{MOhm} \cdot \mathrm{m}$ (dolomite) with an average of $3.827 \mathrm{Ohm} \cdot \mathrm{m}$. Major variations in the resistivity values of the samples are due to inhomogeneities in the texture of rocks (the presence of clay and sandy layers) and their disarray. Specific electrical resistivity of rock samples, saturated by synthetic brine (solution of 
Table 1.

\begin{tabular}{|c|c|c|c|c|c|c|c|c|c|c|c|c|}
\hline \multirow[b]{2}{*}{$\begin{array}{c}\text { Index } \\
\quad \#\end{array}$} & \multirow[b]{2}{*}{ Rock } & \multirow[b]{2}{*}{ Age } & \multirow{2}{*}{$\begin{array}{l}\text { Para- } \\
\text { meter } \\
\text { value }\end{array}$} & \multicolumn{2}{|c|}{ Density $\left[\mathrm{kg} / \mathrm{m}^{3}\right]$} & \multicolumn{2}{|c|}{ Open porosity [\%] } & \multirow{2}{*}{$\begin{array}{l}\text { Perme- } \\
\text { ability } \\
10^{-15} \cdot \mathrm{m}^{2}\end{array}$} & \multirow{2}{*}{$\begin{array}{l}\text { Residual } \\
\text { water } \\
\text { saturation } \\
\text { factor }\end{array}$} & \multicolumn{2}{|c|}{ Resistivity } & \multirow{2}{*}{$\begin{array}{c}\text { Relative } \\
\text { resistivity } \\
F_{R}\end{array}$} \\
\hline & & & & dry & $\begin{array}{l}\text { saturated } \\
\mathrm{NaCl}\end{array}$ & $\begin{array}{c}\text { by } \\
\text { nitrogen }\end{array}$ & $\begin{array}{c}\text { saturated } \\
\mathrm{NaCl}\end{array}$ & & & $\begin{array}{c}\text { dry, } \\
\text { MOhm } \cdot \mathrm{m}\end{array}$ & $\begin{array}{c}\text { saturated } \\
\mathrm{NaCl}, \\
\mathrm{Ohm} \cdot \mathrm{m}\end{array}$ & \\
\hline 1 & 2 & 3 & 4 & 5 & 6 & 7 & 8 & 9 & 10 & 11 & 12 & 13 \\
\hline 1 & limestone & \multirow{9}{*}{ 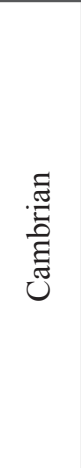 } & $\min$ & 2661 & 2673 & 0.010 & 0.002 & 0.001 & 0.030 & 0.131 & 50.5 & 143.9 \\
\hline 2 & limestone & & $\max$ & 2699 & 2704 & 0.025 & 0.013 & 3.479 & 0.670 & 6.588 & 72.9 & 207.6 \\
\hline 3 & limestone & & avg & 2690 & 2695 & 0.016 & 0.006 & 0.442 & 0.269 & 1.423 & 66.2 & 188.6 \\
\hline 4 & dolomite & & $\min$ & 2690 & 2694 & 0.017 & 0.005 & 0.001 & 0.300 & 0.147 & 28.7 & 81.7 \\
\hline 5 & dolomite & & $\max$ & 2845 & 2854 & 0.046 & 0.038 & 0.002 & 0.650 & 24.442 & 69.8 & 198.7 \\
\hline 6 & dolomite & & avg & 2753 & 2766 & 0.026 & 0.017 & 0.001 & 0.410 & 6.412 & 54.6 & 155.6 \\
\hline 7 & sandstone & & $\min$ & 2116 & 2222 & 0.054 & 0.044 & 0.005 & 0.270 & 0.052 & 7.2 & 20.4 \\
\hline 8 & sandstone & & $\max$ & 2486 & 2526 & 0.130 & 0.116 & 1.067 & 0.860 & 11.128 & 30.0 & 85.5 \\
\hline 9 & sandstone & & avg & 2290 & 2361 & 0.089 & 0.077 & 0.139 & 0.710 & 3.648 & 15.5 & 44.1 \\
\hline
\end{tabular}

$\mathrm{NaCl}$ ), ranges from 7.2 (sandstone) to $73 \mathrm{Ohm} \cdot \mathrm{m}$ (limestone) with an average value of $45 \mathrm{Ohm} \cdot \mathrm{m}$.

The laboratory studies showed the following correlation (Fig. 2a, 2b, 2c) between porosity $(\phi)$ and the formation resistivity factor $\left(F_{R}\right): F=a \cdot \phi^{-m}-$ Archie-Dahnov Equation for sandstone, limestone and dolomite, respectively, where $a$ is constant coefficient, and $m$ - structural indicator [2].

Electrical resistivity can be quantified using Archie-Dahnov Equation: $F_{R}=1.675 \cdot \phi^{-1.22}$ when $R^{2}=0.84$ (sandstone), $F_{R}=40.99 \cdot \phi^{-0.27}$, when $R^{2}=0.77$ (limestone),
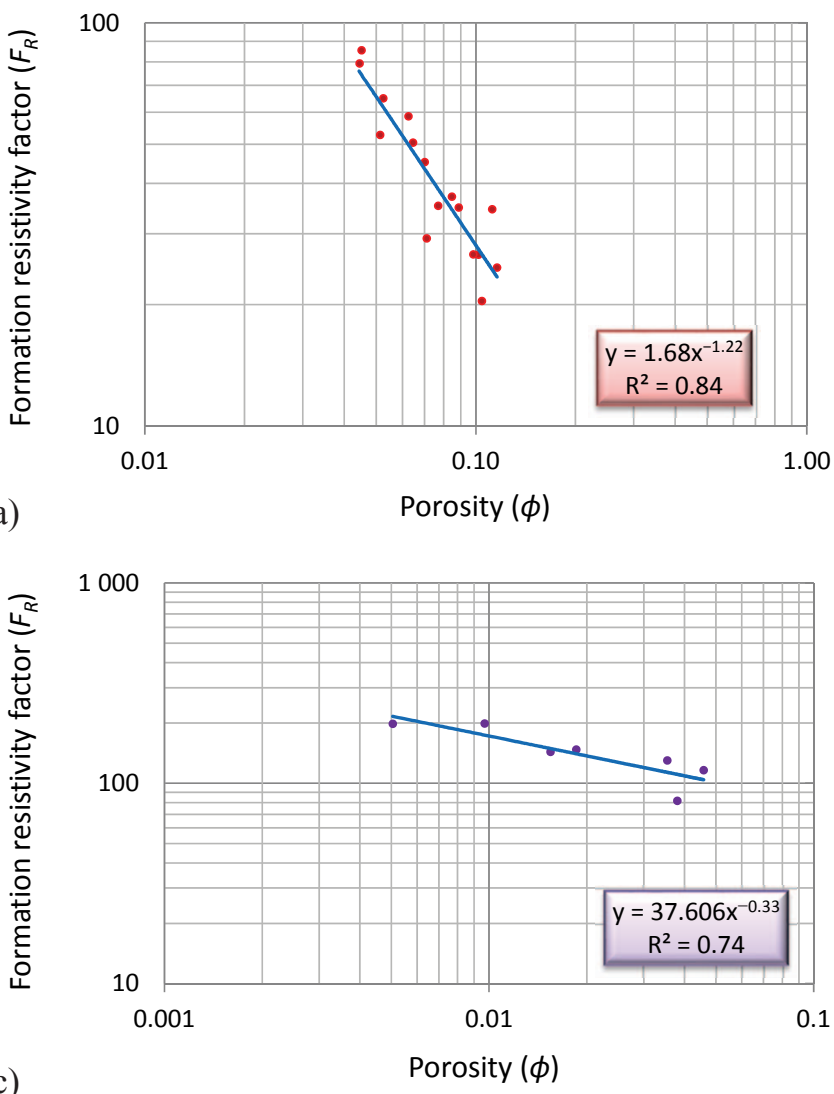

$F_{R}=37.60 \cdot \phi^{-0.33}, R^{2}=0.74$ (dolomite), where $-F_{R}=R^{0} /$ $R_{W}, R^{0}$ - the resistivity of the $100 \%$ water saturated rock, $R_{W}$ - electric resistivity of reservoir water.

Data analysis showed that in sandstones, changes in formation resistivity factor range from 20.4 to 85.5, with an average value of 50. Accordingly, porosity variation is within the range of 0.089 to 0.116 , with an average value of 0.077 . For limestone, variation in formation resistivity ranges from 143.9 to 207.6 , with an average value of 180 , whereas porosity varies from 0.002 to 0.015 , with an average value

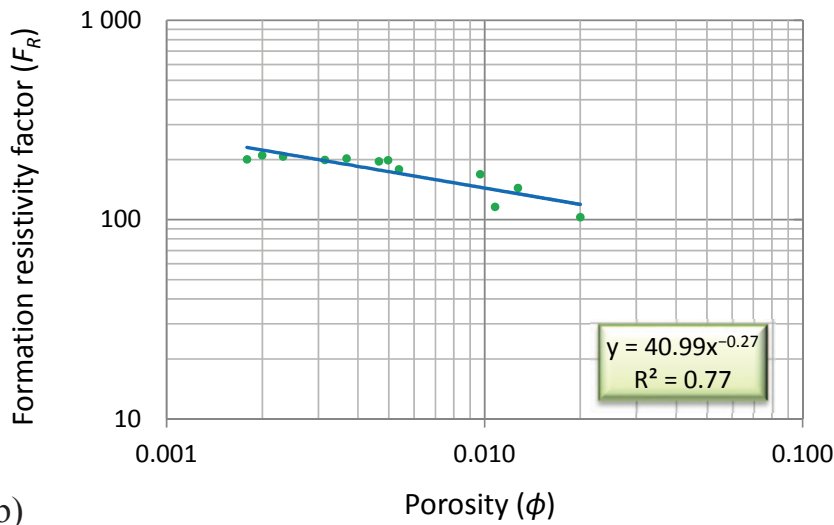

Fig. 2. Correlation between porosity $(\phi)$ and the formation resistivity factor $\left(F_{R}\right)$ - Archie-Dahnov Equation (laboratory conditions): $\mathrm{a}$ - sandstone, $\mathrm{b}$ - limestone, $\mathrm{c}$-dolomite 
of 0.008 . Dolomites show variation in formation resistivity factor ranging from 81.7 to 198.7 , with an average value of 145 , and porosity variation of 0.005 to 0.038 , with an average value of 0.017 .

Limestone and dolomite from Volodymyrska area show little difference in the values: coefficient $a$ is 41 and 36.6 respectively, and the structural index $m-0.273$ and 0.33 . On the other hand, for sandstones from Volodymyrska area, coefficient $a$ is 1.675 , and structural index $m-1.124$, these values being markedly different from those above.

We used the centrifuge OS-6M in our laboratory experiment and carried out statistical analysis of electrical measurements, to determine the correlation dependences between resistivity index $\left(I_{R}\right)$ and water saturation factor $\left(S_{w}\right)$ for the rocks under study. Correlation dependences are as follows: for sandstones $-I_{R}=1.069 \cdot S_{w}^{-0.92}$, with $R^{2}=0.82$, for the limestones the relationship is: $I_{R}=1.169 \cdot S_{w}^{-0.79}$, with $R^{2}=0.86$; dolomites dependence can be expressed by the following formula: $I_{R}=0.997 \cdot S_{w}^{-0.87}$, with $R^{2}=0.79$, where $I_{R}=R_{t} / R_{\mathrm{o}}, R_{t}$ - partially water-saturated rock resistivity and $R_{\mathrm{o}}$ is water-saturated rock resistivity. Figures $3 \mathrm{a}, 3 \mathrm{~b}$ and $3 \mathrm{c}$ show the correlations.

Data analysis shows that the sandstones have a resistivity index ranging from 1 to 3.23, with an average value of 1.24. Accordingly, water saturation factor ranges from 1 to 0.29 , with an average value of 0.88 . For limestones, resistivity index variation is from 1 to 7.19 , with an average value of

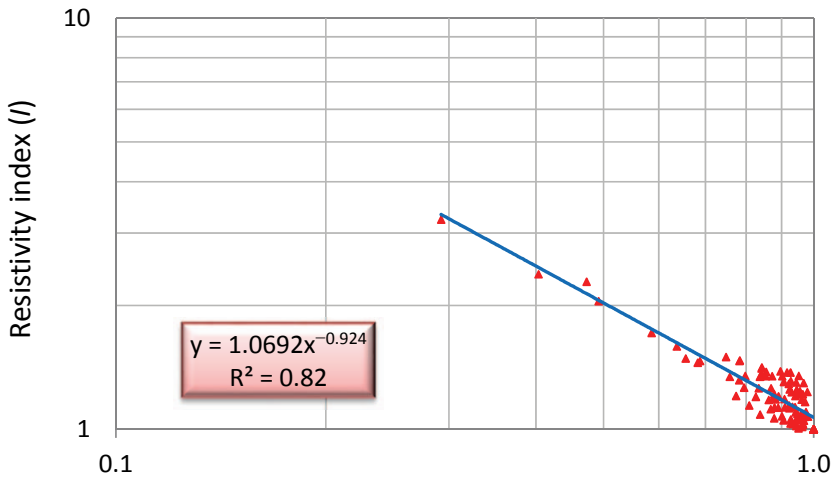

a)

Water saturation factor $(S w)$

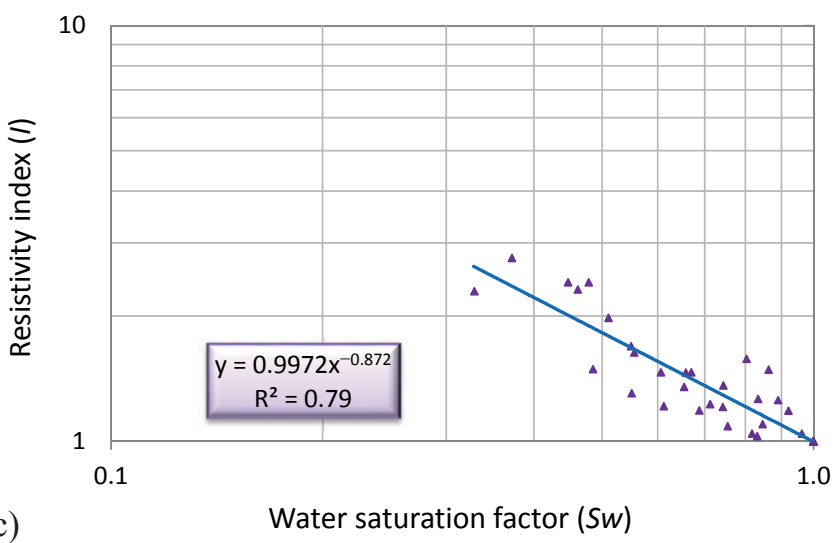

2.24 and water saturation factor ranging from 1 to 0.08 , with an average value of 0.48 . For dolomites, resistivity index ranges from 1 to 2.76, with an average value of 1.44 and the corresponding water saturation factor varying from 1 to 0.33 , with an average value of 0.71 .

It should be noted, that in the correlation equation $I_{R}=b \cdot S_{w}^{-n}$ which expresses the relationship between water saturation factor and resistivity index, coefficient $b$ varies from 0.997 (dolomites) to 1.17 (limestones), and wettability index $n$ ranges from 0.79 (limestones) to 0.92 (sandstones). The rocks under study show small difference in these attributes.

To evaluate specific resistivity of rocks under reservoir conditions, we carried out a comprehensive study using a special installation for high pressure - VSC-1000, with pressure ranging from the atmospheric pressure to $59 \mathrm{MPa}$. The results clearly show that under increasing pressure, closing of microcracks and deformation of the pore space result in an increase of the electrical resistivity of rocks. We were able to define the correlation between mean resistivity increasing coefficient $(Q)$ and pressure $(p)$ for sandstones and limestones. This relationship can be expressed by polynomials of order 3 and 4:

$$
\begin{gathered}
Q=1 \cdot 10^{-5} \cdot p^{3}-13 \cdot 10^{-4} \cdot p^{2}+5.9 \cdot 10^{-2} \cdot p+0.9993, \\
\text { with } R^{2}=0.99 \text { (sandstones), }
\end{gathered}
$$

$Q=-8 \cdot 10^{-6} \cdot p^{4}+9 \cdot 10^{-4} \cdot p^{3}-2.98 \cdot 10^{-2} \cdot p+4.022 \cdot p+0.4302$, with $R^{2}=0.99$ (limestones).

Figures $4 \mathrm{a}$ and $4 \mathrm{~b}$ show this relationship.

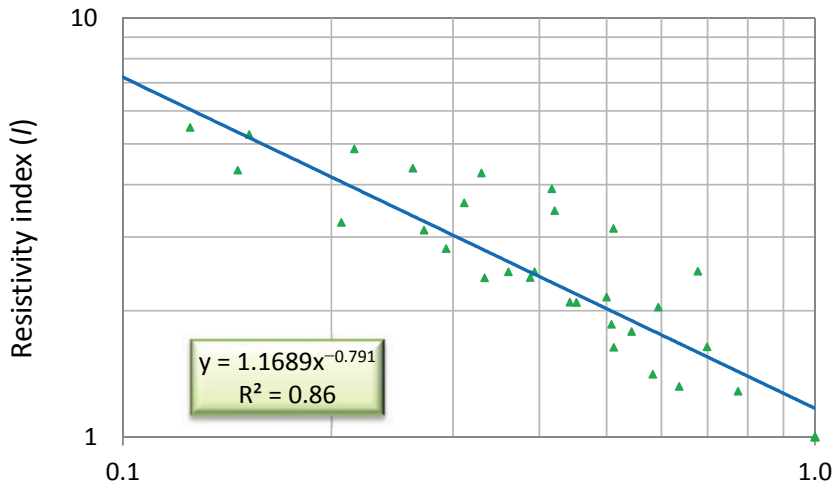

b)

Water saturation factor $(S w)$
Fig. 3. Correlation dependence between water saturation factor $\left(S_{w}\right)$ and resistivity index $\left(I_{R}\right)$ : a - sandstones, $\mathrm{b}-$ limestones, $\mathrm{c}-$ dolomites 


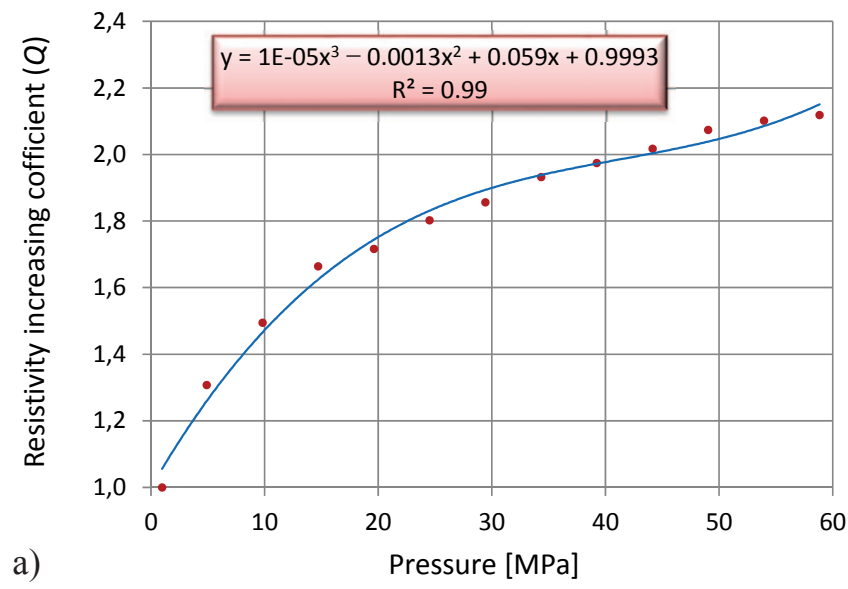

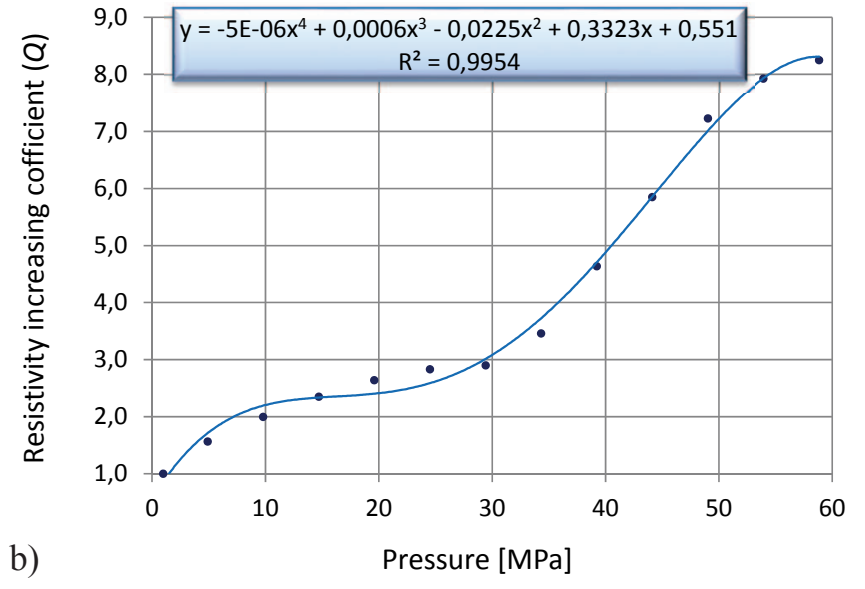

Fig. 4. Correlation between the resistivity increasing coefficient $(Q)$ and pressure $(p)$ for: sandstones (a) and limestones $(b)$

Sandstones show a variation of resistivity increasing coefficient ranging from 1 to 2.12 , with an increase in the hydrostatic pressure from the atmospheric pressure up to $59 \mathrm{MPa}$. For the limestones, the variation range of resistivity increasing coefficient is from 1 to 8.3 , with an increase in the hydrostatic pressure from the atmospheric pressure up to $59 \mathrm{MPa}$.

Graphs in Figure 4 suggest that there are three areas showing marked differences in the nature of electric resistivity variation. In the first area, where pressure ranges from the atmospheric pressure to $24.5 \mathrm{MPa}$, resistivity increasing coefficient is very high - up to 1.8 for sandstones. This may be caused by intense closing of microcracks, which reduces channels conductivity. The following range of pressure variation - from 24.5 to $44 \mathrm{MPa}$ - is associated with a certain stabilization of electrical resistivity variation. In this case, the coefficient of resistivity increasing ranges from 1.8 to 2 for sandstones. In the range of pressures from 44 to $59 \mathrm{MPa}$ resistivity increasing coefficient is lower than in the first range, but higher than in the second one. The slow growth rate of coefficient of resistivity increasing in the ranges (plots) 2 and 3 may be accounted for, by relatively smaller (than in the first range) deformations of the pore space, which constricts or breaks the conduction channels. For limestones, in the first section (pressure increases from atmospheric to $9.8 \mathrm{MPa}$ ) the coefficient of resistivity increasing varies from 1 to 2 . In the range of pressures from 9.8 to $29 \mathrm{MPa}$, there is some stabilization in electrical resistivity variation to be observed. With pressure increasing above $30 \mathrm{MPa}$, the coefficient of resistivity increasing rises sharply (up to 8.3 at a pressure of $59 \mathrm{MPa}$ ). This is probably due to abrupt closing of major cracks responsible for electrical conductivity.

Using the data on measuring resistivity under pressure, we calculated its values for the rocks under reservoir conditions. A petroelectrical study with high pressures applied, enabled us to define the relationship between porosity $(\phi)$ and forma- tion resistivity factor $\left(F_{R}\right)$. The Archie-Dahnov Equation for the Cambrian sandstones (under reservoir conditions) is as follows (Fig. 5): $F_{R}=1.365 \cdot \phi^{-1.52}$ with $R^{2}=0.92$.

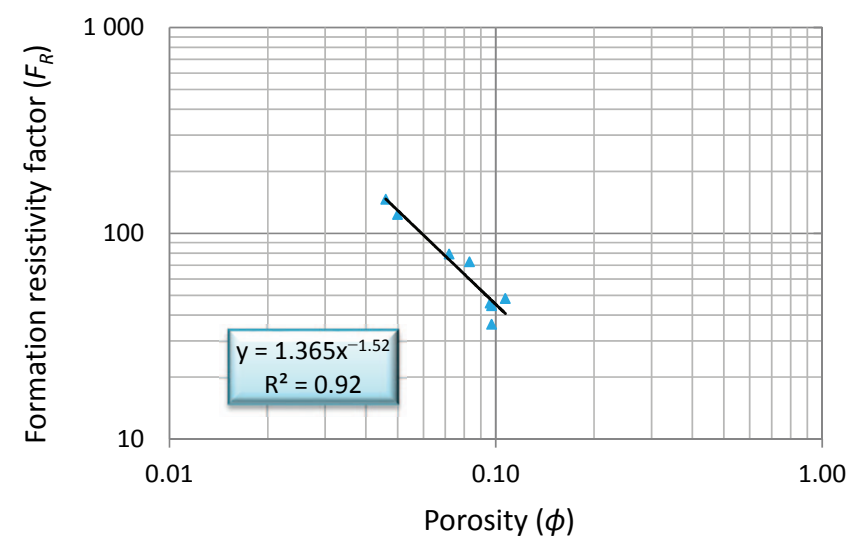

Fig. 5. Correlation between porosity $(\phi)$ under reservoir conditions and formation resistivity factor $\left(F_{R}\right)$ under reservoir conditions for the Cambrian sandstones

To evaluate electrical anisotropy, we took measurements of electrical resistivity along and across the stratification. Resistivity anisotropy coefficient $\lambda$ was determined using the formula:

$$
\lambda=\sqrt{\frac{R_{v}}{R_{h}}}
$$

where $R_{h}$ and $R_{v}$ - electrical resistivity along and across stratification respectively.

The results show that the resistivity anisotropy coefficient of dry extracted sandstones varies from 1.01 to 1.09 with an average value of 1.05. Anisotropy factor of saturated (solution of $\mathrm{NaCl}$ ) sandstones varies from 1.05 to 1.18 with an average value of 1.12 .

Comprehensive analysis of a petrophysical data set, was the basis for determining petroelectrical models of conser- 
Table 2. Petroelectrical models of rocks (wells Volodymyrska-1 and Volodymyrska-2, the interval 1190-2520 m) from Volodymyrska area

\begin{tabular}{|c|c|c|c|c|}
\hline \multirow{2}{*}{$\begin{array}{c}\text { Index } \\
\quad \#\end{array}$} & \multirow{2}{*}{$\begin{array}{l}\text { Petroelectrical parameter/ } \\
\text { Correlation dependence }\end{array}$} & \multicolumn{3}{|c|}{$\begin{array}{l}\text { Parameter variation range (average)/ } \\
\text { Correlation equation (correlation coefficient) }\end{array}$} \\
\hline & & Sandstone & Limestone & Dolomite \\
\hline 1 & 2 & 3 & 4 & 5 \\
\hline 1 & $\begin{array}{c}\text { Electrical resistivity of dry extracted } \\
\text { samples, MOhm } \cdot \mathrm{m}\end{array}$ & $\begin{array}{l}0.052-11.128 \\
(3.647)\end{array}$ & $\begin{array}{c}0.131-6.588 \\
\quad(1.423)\end{array}$ & $\begin{array}{c}0.147-24.442 \\
(6.412) \\
\end{array}$ \\
\hline 2 & $\begin{array}{l}\text { Electrical resistivity of rock samples, } \\
\text { saturated with synthetic brine } \\
\text { (solution of } \mathrm{NaCl}), \mathrm{Ohm} \cdot \mathrm{m}\end{array}$ & $\begin{array}{l}7.2-30 \\
(17.6)\end{array}$ & $\begin{array}{l}50.5-72.9 \\
\quad(63.2)\end{array}$ & $\begin{array}{l}28.7-69.8 \\
\quad(51)\end{array}$ \\
\hline 3 & $\begin{array}{l}\text { Formation resistivity factor }\left(F_{R}\right) \\
\text { in laboratory conditions }\end{array}$ & $\begin{array}{l}20.4-85.8 \\
(50)\end{array}$ & $\begin{array}{c}143.9-207.6 \\
(180)\end{array}$ & $\begin{array}{c}81.7-198.7 \\
(145)\end{array}$ \\
\hline 4 & $\begin{array}{l}\text { Formation resistivity factor }\left(F_{R}\right) \\
\text { under reservoir conditions }\end{array}$ & $\begin{array}{c}36.1-146.2 \\
(75)\end{array}$ & & \\
\hline 5 & $\begin{array}{c}\text { Archie-Dahnov dependence } \\
\text { (laboratory conditions) }\end{array}$ & $\begin{array}{c}F_{R}=1.675 \cdot \phi^{-1.224} \\
R^{2}=0.84\end{array}$ & $\begin{array}{c}F_{R}=41 \cdot \phi^{-0.273} \\
\quad R^{2}=0.77\end{array}$ & $\begin{array}{l}F_{R}=37.6 \cdot \phi^{-0.33} \\
\quad R^{2}=0.74\end{array}$ \\
\hline 6 & $\begin{array}{l}\text { Archie-Dahnov dependence } \\
\text { (under reservoir conditions) }\end{array}$ & $\begin{array}{c}F_{R}=1.365 \cdot \phi^{-1.519} \\
R^{2}=0.92\end{array}$ & - & - \\
\hline 7 & $\begin{array}{c}\text { Resistivity anisotropy coefficient } \\
\text { of dry extracted samples }\end{array}$ & $\begin{array}{c}1.01-1.09 \\
(1.05) \\
\end{array}$ & - & - \\
\hline 8 & $\begin{array}{l}\text { Resistivity anisotropy coefficient } \\
\text { of rock samples, saturated with } \\
\text { synthetic brine (solution of } \mathrm{NaCl} \text { ) }\end{array}$ & $\begin{array}{l}1.05-1.18 \\
(1.12)\end{array}$ & - & - \\
\hline 9 & Resistivity index $\left(I_{R}\right)$ & $\begin{array}{c}1-3.23 \\
(1.24)\end{array}$ & $\begin{array}{c}1-7.19 \\
(2.8)\end{array}$ & $\begin{array}{c}1-2.76 \\
(1.43) \\
\end{array}$ \\
\hline 10 & $\begin{array}{l}\text { Correlation between water saturation } \\
\text { factor }\left(S_{w}\right) \text { and resistivity index }\left(I_{R}\right)\end{array}$ & $\begin{array}{c}I_{R}=1.069 \cdot S_{w}^{-0.92} \\
R^{2}=0.82\end{array}$ & $\begin{array}{c}I_{R}=1.169 \cdot S_{w}^{-0.79} \\
R^{2}=0.86\end{array}$ & $\begin{array}{c}I_{R}=0.997 \cdot S_{w}^{-0.87} \\
R^{2}=0.79\end{array}$ \\
\hline 11 & $\begin{array}{l}\text { Correlation between the of } \\
\text { resistivity increasing coefficient }(Q) \\
\text { and pressure }(p)\end{array}$ & $\begin{array}{c}Q=1 \cdot 10^{-5} \cdot p^{3}-13 \cdot 10^{-4} \\
p^{2}+5.9 \cdot 10^{-2} \cdot p+0.9993 \\
R^{2}=0.99\end{array}$ & $\begin{array}{c}Q=-8 \cdot 10^{-6} \cdot p^{4}+9 \cdot 10^{-4} \\
p^{3}-2.98 \cdot 10^{-2} \cdot p^{2}+ \\
4.022 \cdot p+0.4302 \\
R^{2}=0.99\end{array}$ & - \\
\hline 12 & $\begin{array}{l}\text { Resistivity increasing coefficient with } \\
\text { pressure ranging from atmospheric } \\
\text { pressure to } 59 \mathrm{MPa}\end{array}$ & $1-2.12$ & $1-8.3$ & - \\
\hline
\end{tabular}

tal sandstones, limestones and dolomites. In this paper, the petroelectrical model is presented in the form of geoelectrical data and relationships between petroelectrical parameters and physical properties of the Volodymyrska area rocks. These data are summarized in Table 2.

Conclusions. It was shown that, being a powerful tool for both laboratory and field studies, geoelectric methods prove to be effective and provide extensive and accurate data on the properties of rocks. Electrical study plays an important role in petrophysics and is widely used in determining the physical properties of rocks. It is obvious, that for solving various tasks in the search and exploration of mineral deposits, particularly in petroleum geology, it is essential in determining the composition, structure and condition of rocks.

Laboratory experiment was conducted in order to determine the electrical attributes of the Cambrian sandstones, limestones and dolomites from Volodymyrska area, which is prospective for hydrocarbons. Our study has revealed the empirical relationships between electrical parameters and filtration-capacitive properties of sandstones, limestones and dolomites, which are essential for the geological interpretation of geophysical data. These relationships are approximated by a power function.

Detailed electrical research into the properties of sandstones, limestones and dolomites has ensured accurate electrical models of these rocks based on geological and geophysical data. The models show significant differences in the electrical parameters of sandstones, limestones and dolomites. These models can become a powerful tool in studying the physical properties of different types of rocks. Further research into electrical properties of rocks will require data on dielectric permeability, dielectric loss tangent, as well as evaluating 
the relevance of of geoelectric parameters which account for variation in electrical resistivity of dry, extracted samples exposed to direct current over longer periods of time and establishing their correlations with logging data.

Please cite as: Nafta-Gaz 2017, no. 2, pp. 90-96, DOI: 10.18668/NG.2017.02.03

Article contributed to the Editor 4.10.2016. Approved for publication 29.11.2016.

\section{Literature}

[1] Dahnov V.: Geophysical methods of assesment of reservoir characteristics and hydrocarbon saturation of rocks. NedraSubsurface 1975, 343 p.

[2] Djebbar T., Donaldson E.C.: Petrophysics: Theory and practice of measuring reservoir rock and fluid transport properties. 2nd ed. Gulf Professional Publishing is an imprint of Elsevier 2004, $881 \mathrm{p}$.

[3] Dortman N.: Petrophysics. Handbook. Part 1. Nedra - Subsurface 1992, $391 \mathrm{p}$.

[4] Dortman N.: Physical properties of rocks and mineral deposits. Geophysics Handbook. Nedra - Subsurface 1984, 455 p.

[5] Parkhomenko E.: Electrical properties of rocks. Nauka - Science $1965,164 \mathrm{p}$

[6] Vyzhva S., Onyshchuk D., Onyshchuk V.: Petroelectrical investigations of reservoir rocks of Western-Shebelynske gas condensate field. Herald of Kyiv University, Geology 2012, vol. 57, pp. 13-16.

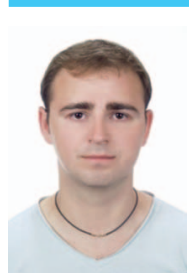

\section{Viktor ONYSHCHUK}

$\mathrm{Ph} . \mathrm{D}$. in Geology

Assistant of the Department of Geoinformatics ESI "Institute of Geology", Taras Shevchenko National University of Kyiv

Ukraine, 03022, Kyiv, 90 Vasylkivska str.

E-mail:vitus16@ukr.net
[7] Vyzhva S., Reva N., Gozhyk A., Onyshchuk V., Onyshchuk I.: Petroelectrical investigations of borehole core of Black Sea shelf. Herald of Kyiv University, Geology 2008, vol. 44, pp. 4-8.

[8] Vyzhva S., Reva N., Gozhyk A., Onyshchuk V., Onyshchuk I.: Petroelectrical investigations of borehole core of complexlybuild reservoir rocks. Herald of Kyiv University, Geology 2010, vol. 50, pp. 4-7.

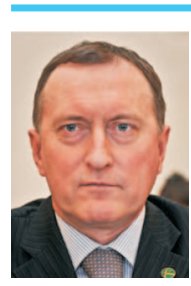

Serhiy VYZHVA

Professor, Doctor of Geology

Head of the Department of Geophysics

Distinguished Educationalist of Ukraine

ESI "Institute of Geology", Taras Shevchenko

National University of Kyiv

Ukraine, 03022, Kyiv, 90 Vasylkivska str.

E-mail: vyzhva_s@ukr.net

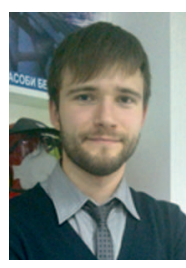

Dmytro ONYSHCHUK

Ph.D. in Geology

Standardization, certification and quality specialist LLC "Ancor Personnel Ukraine"

Ukraine 03680, Kyiv, Business Center Olimpiyskyi,

72 Velyka Vasylkivska str.

E-mail:dmytrij48@gmail.com 